\section{Islamic Banking and Finance Review}

\section{=IBFF}

\section{The Role of Awqaf in Modern Economic Development}

Dr. Mohamad Hisham Dafterdar

Senior Advisor International Islamic

Institute of Waqf Malaysia, Malaysia.

dafterdar@yahoo.com

Research Paper Information:

\section{Jo cite this article}

Dafterdar, M. H. (2015). The role of Awqaf in modern economic development. Islamic Banking and Finance Review, 2 (1), 41-57.

$\underline{\text { Crossref }}$

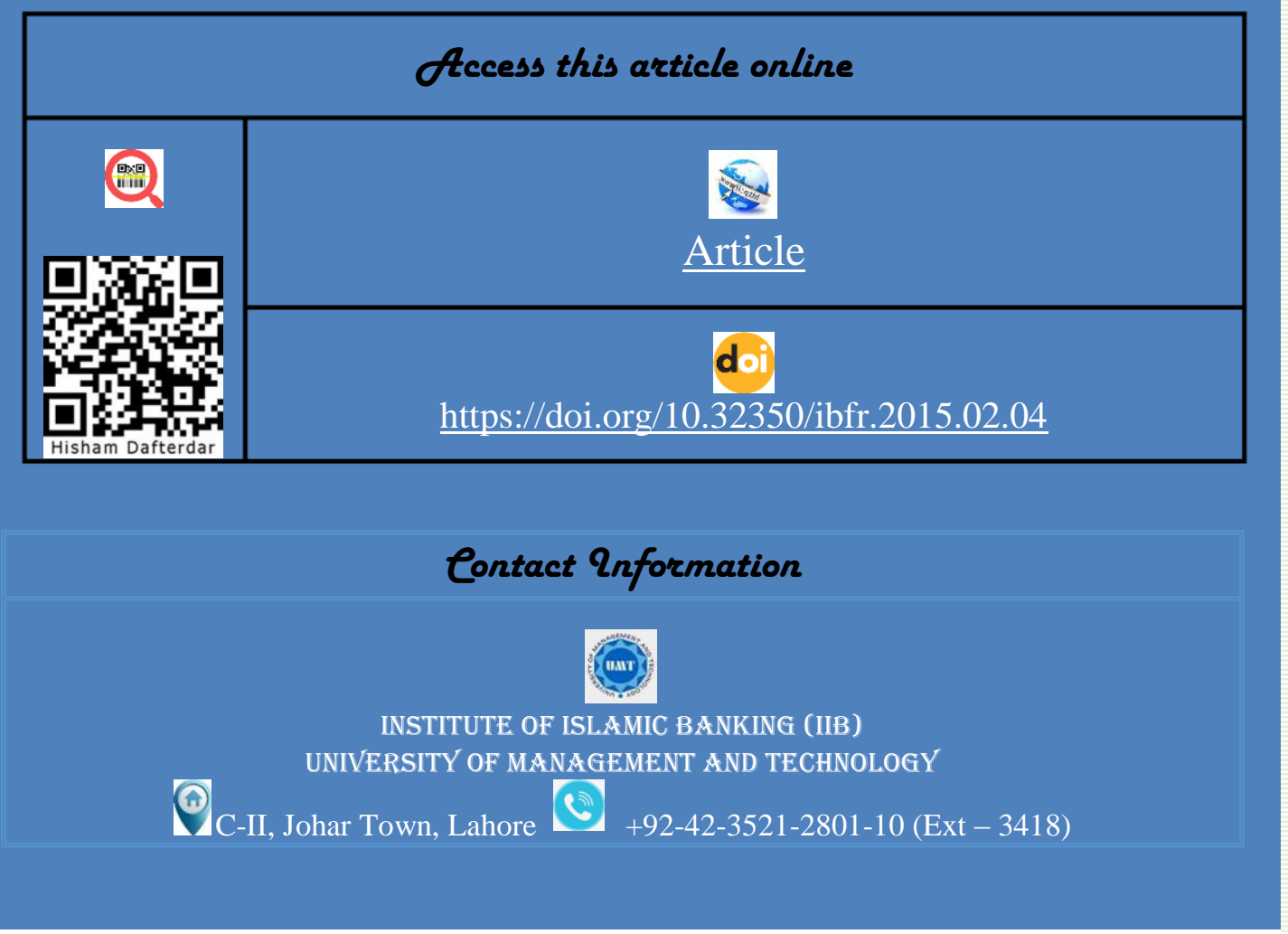

Volume 2

ISSN (E):

1436-H/ 2015

ISSN (P):

2413-2977

2221-5239

\section{Journal do)}

https://doi.org/10.32350/ibfr

$$
\text { Issue do: }
$$

https://doi.org/10.32350/ibfr.2015.02

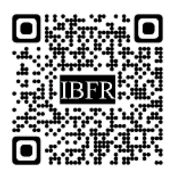

๖

This is an Open Access Journal

\section{Published By}

Institute of Islamic Banking

University of Management and

Technology (UMT)

\section{羿}

https://iib.umt.edu.pk/ibfr/home.aspx

(2)

ibfr@umt.edu.pk

This article is distributed under the terms of Creative Commons

Attribution - Share Alike 4.0

International License.

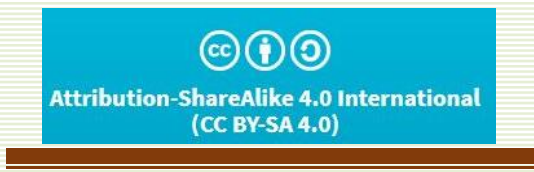

Indexing Partners

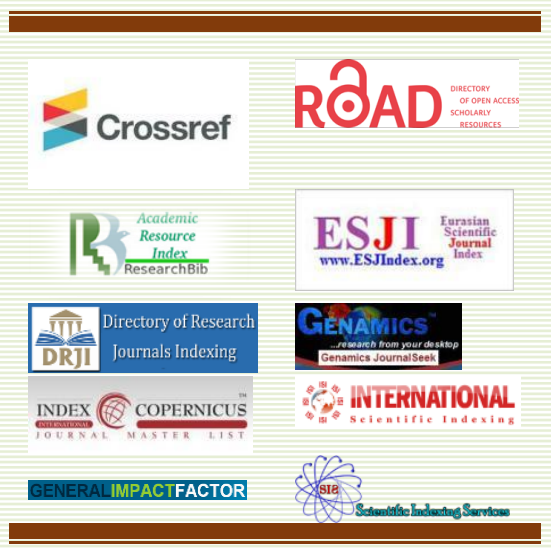




\title{
The Role of Awqaf in Modern Economic Development
}

\author{
Dr. Mohamad Hisham Dafterdar \\ Senior Advisor \\ International Islamic Institute of Waqf \\ Malaysia \\ dafterdar@yahoo.com
}

\begin{abstract}
$\mathrm{I}$

$n$ recent years, there has been an increasing awareness of the role of awqaf in socio-economic development. The importance of this sector is seen in terms of the huge assets it controls, in its social expenditure, in the number of people it employs, and in its significant contribution to the economy which accounts for as much as ten percent of the GDP of many countries. With such significant economic output and growth in the number of non-profit organizations entrusted with awqaf properties for social programs, the sector is no longer seen as exclusively religious. With a broader business focus, it became clear that awqaf, in an economic sense, is an industry and is being subjected to increased scrutiny by government and regulatory authorities. This paper addresses concept of awqaf with respect to the economic development starting by the giving a historical review of the role of awqaf in the Muslim society, the status of awqaf today, awqaf organizations today and their contribution to the economy. The paper also focuses on issues that are relevant for the integration of awqaf into the mainstream of the Islamic financial industry. It also addresses the matters that are of concern to regulatory authorities and stakeholders.
\end{abstract}

Keywords: Awqaf, Economic Development, Waqf, Sunnah, Profitability, Small and Medium Enterprises

Daftedar, Mohamad. Hisham. (2015). The Role of Awqaf in Modren Economic Development. Islamic Banking and Finance Review, 2(1), 41-57. ISSN 2221-5239. (C) 2015 


\section{Introduction}

The institution of waqf is a sunnah established by the Holy Prophet that later became the base on which Islamic socio-economic development model was built. As a feature of the Islamic civilization, the history of awqaf is rich with impressive achievements in the field of social work and human development. Awqaf served the poor in particular and society in general. Awqaf services ranged from education and healthcare to economic development and social welfare. Masjids and shrines (holy places), major hospitals and universities, libraries and museums, animal shelters and sanctuaries were established as waqf. Awqaf also contributed to the protection of the environment and the preservation of religious and cultural heritage.

Despite these achievements, the history of awqaf is rife with turbulent events. Over the years because of number of factors including the legacy of the colonization of Muslim countries, the role of the waqf as an effective tool for socio-economic development was neglected and often forgotten. After independence, many governments considered awqaf as public property and part of the national wealth. They established ministries and directorates as government agencies to manage awqaf as a public sector instrumentality. Thus, awqaf fell into the hands of the state that gave them right of control and managing its administrative expenses from the general budget.

The government control on awqaf did more to stifle the sector than to revive it. In many Muslim countries today, awqaf has not been able to fulfill its purpose as a driver of economic growth. One of the major impediments to its growth is the lack of proper legal environment. While awqaf have generally been overlooked, a few countries did embark on developing this sector and built substantial portfolios of awqaf properties and investments (Dafterdar \& Fund, 2007). They recognized the potential of awqaf as an effective economic sector with a social role to combat poverty and enhance welfare.

\section{Historical Overview}

The institution of waqf played a significant developmental role throughout Islamic history. The concept of endowment of property of permanent nature 
by a Muslim as an ongoing charity was put forward by the Noble Prophet The practice of waqf was known before the advent of Islam. However, Islam is the first religion to develop a comprehensive regulatory framework that promotes guides, protects and fosters the development of the institution of waqf. Everything that the West developed later on in this field is a copy.

From the earliest days of Islam, awqaf has featured prominently in the social and economic development of Muslim societies. Awqaf was the main provider of many social services that today are being financed by the state such as education, healthcare, infrastructure and national security. Awqaf was also the means of achieving equitable distribution of income and wealth and introducing inter-generational social investments in society. The foundation of waqf reached its zenith during the $16^{\text {th }}$ and $17^{\text {th }}$ century, as many sultans and prominent people created numerous waqf's in the form of masjids, schools, hospitals, shelters and agricultural land (Roded, 1990). It was reported by Khaf (2003) that more than half of the agricultural land of Ottoman Empire was waqf, for providing food and creating employment.

By the end of the $20^{\text {th }}$ century, many Muslim governments had established ministries, directorates that placed awqaf firmly under government control. The control by governments had several negative impacts on the waqf system that led not only less development of new awqaf, but also to the expropriation of large areas of awqaf land. Many awqaf properties were left undeveloped or fell into a state of disrepair and much of the latent wealth of awqaf remains to date largely untapped. The role of awqaf as a welfare mechanism declined to such extent that in many countries it became a burden on the public purse.

The recent economic downturns have drawn attention to the Islamic economic system and its faith-based institutions of zakat and waqf (Raimi et al, 2014). Many Muslim countries embarked on reforming the administration of awqaf by separating the custody (nazara) function from awqaf asset management by establishing separate entities to manage awqaf properties. They conceded that the waqf has a separate personality 'thimmab' and that awqaf funds are not to be commingled with public funds. In 1971 "Egyptian Awqaf Authority" was established in Egypt to take over the management of awqaf properties from the Ministry of Awqaf. In Sudan, the "Federal 
Corporation of Awqaf” was established in 1987 and in 1993 “Awqaf Public Foundation" was founded in Kuwait. In Jordan, the Ministry of Awqaf, Islamic Affairs and Holy Places established "Awqaf Properties Investment Corporation". In Malaysia, at the federal level, the Prime Minister's Department in 2004 established the Jabatan Wakaf, Zakat dan Haji department for Awqaf, Zakat and Hajj to coordinate the activities of the states' religious councils in matters relating to awqaf development.

\section{The Third Economic Sector}

A number of Shariah scholars are of the view that once a property is offered as a waqf, it should remain a waqf forever (Khaf, 1992; Mohammad et al., 2006; Toraman, 2007). This condition of perpetuity of a waqf asset, has led over the years to a considerable accumulation of societal wealth that played an important role in improving the Muslim community. As a reflection of waqf increasing contribution to the economy, awqaf as a non-profit institution has come to be known as the third sector, as distinct from the government sector also known as the first sector, and the private sector sometimes called the second sector. The distinction of this third sector from the other two is based on awqaf's altruistic ethos.

Awqaf organizations are not-for-profit Islamic entities with a diversity of structure and purpose. Awqaf are not part of government although many perform a public service. Awqaf generate economic value although many of the benefits are non-quantifiable. Their operations dovetail into all sectors of the economy and include a wide range of industries including real estate, education, healthcare, social services and recreation. Awqaf play a significant role especially in areas where public services are lacking or insufficient, and where the private sector does not find it profitable to invest. Awqaf are the major force in the national economy with a huge impact on the welfare and lifestyle of the community.

\section{Custody and Management of Awqaf}

In principle, the waqif through a deed determines the objectives of the waqf and its management and succession processes. The waqf manager or trustee (mutawalli/nazir) holds the title of the waqf property, exercises legal control and is bound by fiduciary responsibility and moral obligation to protect and 
administer the waqf for the benefit of the beneficiaries in accordance with the terms of the waqf deed. Mutawallis are expected to comply with both the letter and spirit of the waqf condition. The importance of the conditions of the waqif is indicated by the often quoted maxim: "The conditions of the waqif have the same legal weight as the edicts of the legislator". However, some flexibility is afforded by the different schools of jurisprudence. Abu Hanifah school of thought, for example, allows changing the conditions of the waqif if there is an overriding public benefit (maslaha a'ama), or when the beneficiaries or the purpose of the waqf come to an end.

The authority of mutawallis to act and make decisions on behalf of the waqf carries an immense responsibility and their duties are wider and more onerous than they were assumed to be. As trustees, mutawallis have the primary responsibility for prudent management of assets in their custody. As such, mutawallis are expected to have a certain level of business skills and investment knowledge to support their role in monitoring the safety and performance of assets under their control. However, because of the nature of awqaf, its religious message and social application, it seems logical that those who are entrusted with the custody and management of awqaf properties are more religiously conscious and therefore employ their faith when managing. But the operating environment is rapidly changing and as a consequence the role of the mutawallis is also changing. Mutawallis are not only required to act in good faith for the best outcomes for the waqf, but also to be seen acting diligently and ethically, and build trust among those they deal with. Due to the unscrupulous behavior of some mutawallis awqaf had lost much of the respect and trust of the community. Mutawallis have to overcome this image problem. They need to develop behavioral characteristics and bring awqaf management into line with community expectation in order to change the traditional image as persons who insular, ignorant, skeptical and are as much a business risk as being concerned mainly with disbursing money rather than managing the waqfs.

\section{Creating an Enabling Legal Environment}

One of the major impediments for the development and growth of awqaf is the lack of constructive legal and regulatory environment (Dafterdar, 2011). Without a good sustainable environment, it is difficult to develop an industry. Awqaf is an economic sector built on voluntary contribution of 
assets and services. Therefore, a regulatory environment can foster public confidence in the waqf, encourage donors, and promote ethical and proactive behavior of employees, volunteers and mutawallis. The donors usually feel more comfortable with organizations whom operations are governed by clear and convincing evidence of accountability and transparency. Also, financiers are more willing to provide capital for projects that adopt the best practices of corporate governance.

Unlike commercial corporations, the services delivered by awqaf may often be intangible and difficult to measure. The companies have clear delineations about shareholders with all reporting geared towards profits. The position is not so simple in case of awqaf organizations, since many awqaf foundations consider regulatory and compliance issues of corporate governance costly and unnecessary administrative burdens. Unlike commercial corporations, staff in an awqaf foundation is comprised of low-paid professionals or volunteers who have chosen to work in awqaf for less tangible rewards. Their loyalty is more to the cause of the waqf than to the organizational entity. They are mainly concerned with the social aspects and pay little attention to financial efficiency. They claim that by legislating what is effectively an issue of faith, the foundation of awqaf will be undermined.

Strategy formulation in an awqaf foundation could be subject to a unique and complex set of influences. An appropriate strategy will be conditioned not to violate the conditions of the waqif, the wishes of the donors and the legal environment. The concerns of non-beneficiary stakeholders should also form part of awqaf foundations' responsibilities and as such mutawallis should have the duty to act in the interest of the entire community. These days no organization is immune from public scrutiny, not even a shelter or an orphanage that does not have a blemish to its name. Therefore the impact of awqaf's performance on the community must be positive and the organization must be seen to be operating in conformity with community standards and expectations.

The major challenge faced by awqaf is ensuring that the massive treasure of awqaf is preserved, developed, continues to grow and contribute to the social and economic development of the Ummah. This can be met only by creating an enabling legal environment - one that creates a level playing field for 
awqaf managers and causes them to be transparent and accountable and enables them to strengthen their operational undertakings in order to fulfill their obligations to donors, beneficiaries and all other stakeholders.

\section{The Business Face of Awqaf}

Awqaf is rapidly developing as a vital economic sector accounting for a substantial share of the Islamic financial system. Being an awqaf organization does not necessarily mean being small. A considerable number of them are large-scale organizations with cross-border operations, controlling substantial assets, and employing significant number of people. Many such major hospitals, universities, museums, and nongovernmental organizations (NGOs) are waqf's. Awqaf organizations have many similarities to private sector corporations. In some ways, it seems there is very little difference to the corporate world - assets need to be managed, bills to be paid, revenues to be earned and reports to be made.

Awqaf also undertake a wide range of activities such as investment, project management, fund raising and maintenance of key banking relationships. There are, however, differences between an awqaf organization and a commercial enterprise. The companies have shareholders and boards, whereas awqaf organizations have donors and trustees. The most fundamental characteristic of an awqaf organization, compared to a commercial enterprise, is that its primary objective is to provide human services, which primarily impacts on the quality of life. The members of an awqaf organization are trustees and custodians, but not owners. Different assets are held for charitable causes and programs. In addition to the poor and needy, awqaf beneficiaries may include public utilities such as mosques, schools, cemeteries, roads, bridges and water wells.

The corporate structure of an awqaf entity underlines the need for adopting some of the concepts and practices of private sector companies. Recently, more and more awqaf organizations are adopting strategic planning and control systems as a form of operational discipline, competing to secure a market position. Awqaf organize their operations along profit and cost centers. Profit centers are created around revenue producing assets, investment portfolios, and fund raising operations. The cost centers are responsible for delivery of their services to beneficiaries. 
Although many fundamental principles of commercial sector strategic planning can be applicable, a thorough appreciation of the features and complexities of the awqaf world can yield much better results (Ahmed, 2004; Dafterdar, 2007). Awqaf governance standards are enshrined in the tenets of Shariah. The Shariah provides the basis for awqaf regulations and the sector shows great concern for ethics based on fundamental values such as honesty, integrity, fairness, trust and commitment. In such areas, awqaf organizations are better placed to regulate their own activities. But awqaf has also to cope with the complexities of the business environment and the increasing demand for more transparency and accountability. Over the decade, there has been a growing realization that although the Shariah serves to provide a general framework for regulating the awqaf sector, it is becoming increasingly important to put forward a comprehensive regulatory framework that is more attuned to market demands.

\section{Sustainability and Profitability of Awqaf}

The dichotomy between sustainability and profitability is false. There is a misconception among people that waqf organizations don't seek profits. The main difference between awqaf and the private sector is that, in the corporate world, profit is used to create individual wealth. In awqaf, the surplus is used to accomplish a mission. Some stakeholders believe that awqaf foundations should distribute the surplus, if there is any, thus the waqf is seen as a flow-through entity or a conduit of income to beneficiaries but not a receptacle to hold it.

There is also a fundamental difference between awqaf and the commercial world in calculating the consequences of business decisions. In companies, decisions are justified in terms of their short term effect on profitability and shareholder value. Awqaf organizations, as trans-generational carriers, have different purposes for generating revenues. Responsible awqaf organizations take a long term view when investing. Their business decisions are commonly considered good if they achieve long term benefits for their beneficiaries.

However, in order to do so, awqaf organizations have to maintain a balance between their mission statement and their financial pursuits. In other words, 
they have to seek a balance between being financially efficient and socially effective. Likewise, an awqaf foundation that is highly effective in meeting its operational objectives, but is inefficient financially, may soon find itself unable to continue delivering services as its resources are drained. Achieving financial sustainability is a goal that all awqaf organizations should strive for. Imagine, for example, an orphanage operated by a waqf foundation. If it does not have any surplus funds to meet ongoing operating and future capital costs, the orphanage may be forced to close down. The inability to access any surplus funds from its own reserves may result in the extraction of much needed community service.

\section{Awqaf Public and Private Sector Partnerships}

Recently, awqaf is getting more attention from both the public and the private sectors. Governments across the Muslim world are becoming more aware of awqaf's potential as an economic driver. This sector is regarded as relatively resilient and recession proof. Awqaf organizations are resistant to market downturns because their assets are unencumbered freehold and they have access to free funds and pro-bono services. Their social mandate is to serve the poor, redistribute wealth and apposite the imbalance between social strata. Their business activities create jobs, produce economic output, stabilize prices and stimulate the economy.

Lately, there is also a growing level of interest and interaction between awqaf and the private sector. The private sector is attracted to the investment opportunities that awqaf business activities offer. Awqaf represent a market niche with good returns (Rahman \& Dean, 2013). The awqaf sector, albeit not-for-profit, and despite its role as a welfare system, appears to have an edge over other sectors because of the many concessions and privileges granted to awqaf projects. At the same time, commercial companies may consider their involvement with awqaf as a way of discharging their corporate social responsibility. Turning a social project into a cash flow project has a special appeal. The partnerships between awqaf and the private sector are more than 'marriage of convenience ${ }^{2}$ ' where under such wedlock, it is usually one party stands to benefit more than the other. Awqaf / private

${ }^{2}$ A marriage or joint undertaking arranged for political, economic, or social benefit rather than from personal attachment. 
sector partnerships should be win-win arrangements that bridge the worlds of private finance and awqaf social responsibility with benefit to both.

From an awqaf perspective, partnership with the private sector is a means of developing awqaf properties through self-financing of projects. The private sector can assist awqaf to deal with the complexities of the business world. The developer is expected to finance the project, carry the risks and operate the project for an agreed period during which the project's cash flow is the only source for repayment of investment and profit. At the end of the agreed period, the facilities are returned to the waqf trustees to become a permanent source of revenue for the organization. Through these partnerships, awqaf organizations are able to pare away non-core functions so they can focus more keenly on their core mission of social work.

\section{Awqaf Support to Small and Medium Enterprises (SMEs)}

Awqaf organizations are viewed as centers of community service and assistance. Awqaf can use the small business model to serve their objectives. Evidence from many countries points to the vital role that partnership between awqaf and small business play in community development. Awqaf can be a catalyst for growth of the small and medium-sized enterprise. Awqaf can raise capital and channel funds into the hands of competent management who have business propositions that have the best prospects of succeeding.

Awqaf's support is not a matter of just providing finance or giving loans to existing small businesses. They build in new capabilities and sustainable ventures. Awqaf organizations can be the "business angels" by entering into partnerships with private entrepreneurs with start-up, early stage and developing businesses. Such partnerships can be of enormous benefit to the project, to waqf organization and to the entrepreneur.

\subsection{Awqaf's Financial Support}

Awqaf's financial support can be in any one of the three main Shariah compliant modes: participatory, concessionary, and project financing

\footnotetext{
${ }^{3}$ An angel investor or angel funder is an affluent individual who provides capital for a business start-up, usually in exchange for convertible debt or ownership equity.
} 
(Hassan, 2010). Within these modes are various contractual forms that conform fully to the principle of profit and loss sharing. Participatory SME financing is the most flexible and most common as it adheres to the Islamic principles of sharing of risks and profits (Hassan, 2010). This is a process wherein awqaf instead of lending money to an enterprise, actually gets involved in the business by sharing as an investor. The more commonly used participatory modes are musharaka (equity participation) and mudaraba (trust financing). From an SME stance, participatory funding is a good alternative to higher cost borrowing. Musharaka participation by awqaf facilitates the transfer of a pre-determined share of the risk in return for a share in the profit. In Mudarabah, awqaf as the finance provider (rabul mal) promotes business development by extending financing to capable but cash-strapped entrepreneurs, based on awqaf carrying the financial risk and sharing the profit at a pre-agreed percentage.

Concessionary financing is money advanced, mainly in the form of, qard basan (benevolent loan) where only the principal is to be repaid or loans at below-market rates - usually for a small service charge to cover administrative cost. The cash waqf is the main source for concessionary SME financing. Concessionary lending can only be considered in very low risk operations and with adequate safeguards to ensure repayment (Hassan, 2010). Project financing modes are usually non-profit sharing as they are based on cost plus a pre-determined mark-up. The financing contracts used include bai muajjal (instalment sales), bai salam (forward sale contracts), ijara (lease financing), ijara wa iqtina (hire-purchase), istisna'a (construction/manufacturing finance), and murabaha (procurement financing). The choice of the mode of financing and the type of contract depends on the nature and needs of the project, the risk profile and expected returns, and on the waqf organization's own investment policy and guidelines.

\subsection{Awqaf's Non-Financial Support}

Awqaf can also provide a range of non-financial support for the smaller enterprise. The most common in-kind contribution is land. The provision of land for a project serves awqaf developmental objectives of waqf properties and ensures permanent connection of the project to the waqf organization. In such arrangements, the appraised current market value of the land is used 
to determine awqaf's share in the project. Other in-kind support includes services such as consultancy and training, guidance and monitoring and insurance. Awqaf organizations can also serve as business incubators for new ventures, nurturing and helping them to survive and prosper. Awqaf can provide advice and guidance and help in areas of strategic planning which can be particularly helpful during the early stages of a business development.

\section{Policy Implication}

With the rise of popular movements like "human rights" and "economic equality", governments in the Muslim world assumed directly responsible for the welfare of their citizens but the role of awqaf was consequently marginalised. However, in spite of government's control, awqaf remained more firmly tied to society than to the state. Government's welfare programs have been unable to serve efficiently all of the social needs, especially the delivery of speedy aid and humanitarian support to vulnerable groups who perceived government's actions with a lot of dissatisfaction and suspicion. On the other hand, faith-based charity institutions such as waqf and zakah enjoy a higher degree of accepted trust, having grass-roots knowledge and much better access to people in need of support than any government agency. Being an act of worship, the practice of waqf as a voluntary act of benevolence gave the awqaf sector public support that contributed to a large degree in shaping its independence.

Given the apparent support for awqaf at the local and national level, the sector needs not to operate at the periphery of socio-economic activity, but should rather be mainstreamed within the state's legal, social and economic systems. The waqf has relations with all areas of social and economic development such as housing, employment, social amenities, investment and commercial activity at zero cost to the state. Therefore, a great deal of thought should go into government policies which impact on the awqaf as it integrated with other sectors of the economy. It is imperative that the impact of any policy of government on awqaf should be positive and not hindering the sector's capacity to grow. The policies which restrict free cash flow could affect awqaf's ability to be of service to its beneficiaries and ultimately to government. Since awqaf's philanthropic and social programs ease the pressure on government's budget, it is fair to assume that the government is 
in fact an indirect beneficiary of awqaf. It is therefore in government's interest to create the supporting environment that promotes public awareness and motivation to make more waqfs. The public and waqf institutions should be incentivized and encouraged through mechanisms such as wassiyah or tax relief.

Awqaf projects exhibit the combined characteristics of being socially responsible, value adding and market oriented. Islamic banks and financing institutions should be encouraged to finance awqaf projects. Both the government and the awqaf institutions should work together to dispel the myth that bankers cannot do awqaf projects and be profitable, and that financing awqaf projects is not just a good idea; it is part of a good business policy.

\section{Concluding Remarks}

Awqaf institutions are effective organizations for the socio-economic, cultural and religious development of a country. They generally have no direct political involvement, although they exercise considerable influence on the country's political and social life. The development of the awqaf sector is on the national agenda of many Muslim countries as a strategy to boost the economy and complement government's social programs. One of the most critical problem awqaf sector is facing is the lack of awareness among people and government as a viable and effective economic sector. Despite the sector's enormous size and significant contribution to the economy, there is hardly news about its importance in the financial pages of newspapers and magazines. Awqaf remains one of the most misunderstood sectors of the Islamic financial system. Awqaf institutions are perceived to lack the organizational discipline and the entrepreneurial acumen of for-profit

corporations. This has resulted in a very slow pace of developing awqaf properties. Hence, this results in many awqaf properties often in prime locations remaining undeveloped or under-utilized.

In many countries the awqaf sector has taken steps towards reinventing itself. In doing so, it has been able to reverse the tendency to write off the sector as being inherently inefficient and has no place for entrepreneurial behavior. Today, awqaf foundations have a broad business focus. They are 
taking responsibility for a wider range of activities in the commercial, industrial, agricultural and services sectors. The areas where guidance is required include institutional, legal and regulatory disciplines. This entails the skilling and empowerment of mutawallis and managers to be effective gate keepers and responsible stewards of the assets under their control, and to enable them to charter the continued growth of their organizations. Legislative reforms and the implementation of a modernized Shariah-based model of corporate governance are needed to remove obstacles that hinder the development of awqaf as a driver of social and economic development in the country.

The renewed interest in awqaf offers an opportunity to learn from the mistakes of the past and to construct a modern regulatory and corporate governance framework. Recognizing that awqaf foundations are non-profit entities holding valuable assets and providing essential social services, government as a beneficiary should create the enabling and supporting environment for the awqaf sector to grow and be more effective. Awqaf's real reform agenda should have succinct, relevant, understandable and implementable standards that optimize efficiency and effectiveness of the sector, and the knowledge, expertise and leadership of awqaf professionals.

However, the sector remains fundamentally constrained and more work needs to be done in order to realize its tangible effect on the economy. With the precise transparency, stability, long term planning and guidance, the prospects for awqaf are great and the more the government assists awqaf, the better the awqaf sector is placed to alleviate the pressure on the public purse and contribute to the country's economic development. Awqaf foundations need a steady stream of revenue in order to fund their operations. They cannot achieve financial sustainability by relying entirely on donations. Many are finding it necessary to expand their revenue base to include steadier forms of income from assets in their custody and from other commercial activities and investments. Thus, their social work is getting more closely entwined with business interests. 


\section{References}

Ahmed, Habib (2007), Legal Environment and Nonprofit Sector: Implications for Growth of Awqaf Institutions, Islamic Research and Training Institute, Islamic Development Bank, Jeddah.

Ahmed, Habib (2004), Roleof Zakah and Awqaf in Poverty Alleviation, Islamic Research and Training Institute, Islamic Development Bank, Jeddah

Ahmed, Hasanudddin (1998), Strategies to develop waqf administration in India, Research paper No. 50, Islamic Research and Training Institute, Islamic Development Bank, Jeddah

Abdul Rahman, R., \& Dean, F. (2013). Challenges and solutions in Islamic microfinance. Humanomics, 29(4), 293-306.

Bello, Dogarawa Ahmad (2009): Poverty Alleviation through Zakah and Waqf Institutions: A Case for the Muslim Ummah in Ghana. Ahmadu Bello University, Zaria-Nigeria.

Brody, Evelyn (2005), "Charity Governance: What's Trust Law Got To Do With It?", Chicago-Kent Law Review, 80, 641-87.

Chapra, M. Umer (1985), Towards a Just Monetary System, The Islamic Foundation, Leicester.

Cizakca, Murat (2000) A History of Philanthropic Foundations:/The Islamic World From the Seventh Century to the Present (Istanbul: Bogazici Univ)

Dallah Albaraka (1994), Fatawa: Shari'ah Rulings on Economics, Dallah Albaraka Group, Research and Development Dept., Jeddah.

Dian Masyila, Muhammad Tasrif, Abdi Suryadinata "A dynamic model for cash waqf management as one of the alternative instruments for poverty alleviation in Indonesia.

Dafterdar, M. H. (2011). Toward Effective Legal Regulations and an Enabling Environment for Inalienable Muslim Endowments (Awqaf). Islam and Civilisational Renewal (ICR), 2(4).

Dafterdar, H., \& Fund, A. P. I. (2007, March). The development and promotion of awqaf as a business sector. In Singapore International Waqf Conference

Edelman, Lauren B. and Mark C. Suchman (1997), "The Legal Environments of Organisations", Annual Review of Sociology, 23, 479515.

Gerber, Haim "The Waqf Institution in Early Ottoman Edirne" Asian and African Studies, 1983, Vol 17, pp 29-45

Hassan, M. K. (2010). An integrated poverty alleviation model combining zakat, awqaf and microfinance. In Seventh International Conference-The Tawhidi Epistemology: Zakat and Waqf Economy, Bangi, Malaysia.

International Fellows in Philanthropy Program (IFPP) (2000), Toward an Enabling Legal Environment for Civil Society, Institute for Policy Studies, 
Center for Civil Society Studies, Johns Hopkins University, Baltimore.

Kahf, Monzer (1999), 'Towards the Revival of Awqaf: A Few Fiqhi Issues to Reconsider', Presented at the Harvard Forum on Islamic Finance and Economics, October 1, 1999.

Kahf, Monzer (2004), "Shari'ah and Historical Aspects of Zakah and Awqaf", background paper prepared for Islamic Research and Training Institute, Islamic Development Bank.

La Zakat et le Waqf: Aspects historiques, juridiques et economiques. Actes de seminaire tenu au Benin du 25 au 31 Mai 1997, edite par Dr. Boualem Bendjilali, Banque Islamique de Developpement, et Istitut Islamique de Recherches et de formation

Makdisi, John A. (1999), "The Islamic Origins of the Common Law", North Carolina Law Review, 77, 1635-1739.

Management and development of awqaf properties - Islamic Development Bank/Islamic Research and Training Institute (IRTI) Seminar No. 16 held in Jeddah from 24/12/1983 to 5/1/10984 edited by Dr. Hassam Abdullah Alamin

Mohammed, Sadig Hammd (2006), "Types of Alarsad and Trusts: A Comparative Study from Islamic Sharia Perspective", paper presented at Seminar on Endowments (Awqaf) in Europe, Birmingham, U.K., March 20-22, 2006.

Mohammad, M. T. S., Iman, M., \& Hamid, A. (2006). Obstacles of the current concept of waqf to the development of waqf properties and the recommended alternative. Malaysian Journal of Real Estate, 1(1), 195.

Roded, R. (1990). Great Mosques, Zāwiyas and Neighborhood Mosques: Popular Beneficiaries of Waqf Endowments in Eighteenth-and Nineteenth-Century Aleppo. Journal of the American Oriental Society, 3238.

Salamon, Lester M. and Stefan Toepler (2000), "Influence of the Legal Environmnet on the Development of the Nonprofit Sector", Working Papers Series No. 17, The Johns Hopkins Center for Civil Societies Studies, Baltimore.

Schwarcz, Steven L. (2003), "Commercial Trusts as Business Organisations", The Business Lawyer, 58, 1-27.

Thomas, Ann Van Wynen (1949), "Note on the Origin and Uses of TrustWaqfs", Southwestern Law Journal, 3, 162-66.

Toraman, C., Tuncsiper, B., \& Yilmaz, S. (2007, August). Cash Awqaf in the Ottomans as philanthropic foundations and their accounting practices. In 5 th Accounting History International Conference, Banff, Canada (pp. 9-11). 
UN-HABITAT 2005 Waqf (Endowment) and Islamic Philanthropy. Paper 7 Islam, Land \& Property Research Series, Nairobi, Kenya

Usmani, M. Taqi (1999), An Introduction to Islamic Finance, Idaratul Maarif, Karachi.

Zaki, Eissa "A summary of waqf regulations" Kuwait Awqaf Public Foundation, Department of Studies \& external Relations 2006AD1427AH, P 7-9

Zarqa, Shaikh Mustafa (1947), Abkam al Waqf, University of Damascus Press, Damascus (in Arabic). 